\title{
Root Associated Bacteria from the Rice antagonizes the Growth of Magnaporthe grisea
}

Yachana $\mathrm{Jha}^{1 *}$ and Subramanian $\mathbf{R B}^{2}$

${ }^{1}$ NV Patel College of Pure \& Applied Sciences, Sardar Patel University, Valbhav Vidhya Nagar, Anand, Gujarat, India ${ }^{2} B R D$ School of Biosciences, Sardar Patel University, Gujarat, India

\begin{abstract}
Root associated bacteria were isolated from the rice field by using nitrogen free selective medium. The biochemical tests and molecular analysis were preformed for the identification of isolates. Then the sequences obtained were analyzed by using bioinformatics software and the cultures were identified as Pseudomonas pseudoalcaligenes, Bacillus pumilus and Stenotrophomonas maltophilia. Then these isolates were in vitro inoculated to paddy plant to study their effect on plant growth promotion and resistance against pathogen. Results obtained during greenhouse showed antagonistic effect of these isolates against Magnaporthe grisea and enhance growth parameters.
\end{abstract}

Keywords: PGPR; Biochemical tests; 16SrDNA; Antibiosis; Greenhouse study; Field assay

\section{Introduction}

One of the finest success stories of the post independent era of India is the green revolution in the 1960s, which transformed the India from a "begging bowl" to a "breadbasket". This has been possible because of the use of chemical fertilizers and hybrid crops. However, in the long run, the use of chemical fertilizers had led to many serious problems, forcing scientists to explore other alternatives. One approach in this direction is the use of biofertilizers, better known as plant growth promoting rhizobacteria (PGPR). Species of root associated bacteria that colonize the rhizosphere of plants and stimulate plant growth by wide array of mechanisms are collectively known as PGPR. PGPR are universally known to enhance the adaptive potential of their host's plants.

The rhizobacteria may be present (i) in the soil surrounding roots, utilizing the metabolites leaked from roots as the growth nutrients, (ii) on the root surface or rhizoplane, (iii) in the root tissue, inhabiting spaces between cortical cells and (iv) inside the cells in specialized root structures or nodules. Host plant-microbial interactions helps in the synthesis of phytohormones which help in plant growth, development and productivity. PGPR, in addition to improvement of plant growth is directly involved in increased uptake of nitrogen, solubilization of minerals, and production of siderophores and make it available to the plant [1].

Rice is one of the world's most important cereal crops, and its protection from disease is vital to the many millions dependent on it as their staple food. Rice suffers from a number of fungal and other diseases in India. Of the common fungal diseases, blast caused by Magnaporthe grisea is the most important. Losses of US $\$ 55$ billions are estimated in Asia only each year due to Magnaporthe grisea [2]. Despite decades of research towards its management, estimated yield losses caused by rice blast every year around the world would be enough to feed 60 million people [3]. Integrated approach like using fungicides, growing resistant varieties, application of organic amendments, balanced nutrition, biological and chemical agents are used to manage rice blast. But extensive use of chemicals may create environmental problems and are costly too. Therefore, more recently there has been a resurgence of interest in environmental friendly, sustainable and organic agricultural practices for the biological control of plant pathogens is an attractive preposition as it mimics the nature's own way of balancing the ecosystem [4]. Furthermore, obvious pollution of the environment and the toxic effects of synthetic chemicals on nontarget organisms including humans have prompted investigations on pesticides of biological origin [5]. During the last couple of decades, the use of PGPR for sustainable agriculture has increased tremendously in various parts of the world due to their efficacy as biological control and highly specific to certain plant species [6]. There is very little information regarding the use of PGPR metabolites as antagonistic agents against fungal pathogen and biofertilizers in rice. The aim of the present work was to select and develop a procedure for the selection of antiphytopathogenic bacterial strains having ability to produce such metabolites and to determine how efficiently it suppress the growth of phytopathogenic fungi in the plant rhizosphere and enhance the plant growth.

\section{Materials and Methods}

\section{Isolation and identification of the bacterial isolates}

Certified seeds of rice were planted in pots and seedlings were used for isolation of PGPR. Bacterial strains were isolated from both the rhizosphere soil and endorhizosphere of rice plants root grown in fields. Bacterial strains were isolated from both the rhizosphere soil and endorhizosphere of rice plants root grown in fields. For rhizosphere soil, clumps of soil loosely adhering to the roots were removed and roots with firmly adhering soil were suspended in sterile $0.85 \mathrm{~g} \mathrm{NaCl} / 100 \mathrm{ml}$ and suspension was used for isolation of rhizosphere bacteria. Then, roots were removed from these suspensions, washed thoroughly with tap water to remove adhering soil particles; surface sterilized and

*Corresponding author: Yachana Jha, NV Patel College of Pure \& Applied Sciences, Sardar Patel University, Valbhav Vidhya Nagar, Anand, Gujarat, India, Tel: +91-9426282152; E-mail: yachanajha@ymail.com

Received January 05, 2013; Accepted February 05, 2013; Published February 10,2013

Citation: Jha Y, Subramanian RB (2013) Root Associated Bacteria from the Rice antagonizes the Growth of Magnaporthe grisea. J Plant Pathol Microb 4: 164 doi:10.4172/2157-7471.1000164

Copyright: @ $2013 \mathrm{Jha}$ Y, et al. This is an open-access article distributed under the terms of the Creative Commons Attribution License, which permits unrestricted use, distribution, and reproduction in any medium, provided the original author and source are credited. 
macerated with a sterile mortar and pestle in sterile $0.85 \mathrm{~g} \mathrm{NaCl} / 100$ $\mathrm{ml}$ for the isolation of endorhizosphere bacteria. Both samples were serially diluted and inoculated into vials containing $5 \mathrm{ml}$ of semi-solid nitrogen-free medium $(\mathrm{NFb})$ with $0.05 \mathrm{~g}$ yeast extract/100 ml. After $48 \mathrm{hrs}$ incubation at $30^{\circ} \mathrm{C}$, one loop of pellicle-forming culture was transferred into fresh semisolid NFb medium. Cultures with subsurface pellicle were streaked into solid $\mathrm{NFb}$ (supplement with $\mathrm{NH} 4 \mathrm{Cl}$ ) and Congo red medium [7]. Distinct colonies were maintained on nutritive agar plates.

\section{Biochemical and molecular identification and characterization of the isolates}

All the isolates were biochemically characterized for utilization of metabolites and enzymes as per the standard methods [8] and $16 \mathrm{~S}$ rDNA analysis was used to identify the isolates. 16S rDNA universal primers 8F:5'AGAGTTTGATCCTGGCTCAG3' and 1510R:5'GGCTACCTTGTTACGTA3' were used for PCR amplification followed by sequencing of PCR amplicons of $16 \mathrm{~S}$ rDNA by Applied Bio Systems ABI PRISM 377 DNA Sequencer (GeNei, Bangalore) [9]. The DNA sequences were analyzed by bioinformatics software and phylogenetic trees were constructed using the neighborjoining method [10].

\section{Antibiotic production}

The antibiotic activity of selected PGPR strain was determined and assessed by extracting and testing toxicity of metabolites produced by them by the method of Kraus and Loper [11]. The strains were grown for $48 \mathrm{hrs}$ in $5 \mathrm{ml}$ of $\mathrm{N}$ broth with glucose $(2 \% \mathrm{w} / \mathrm{v})$. The culture was centrifuged at 10,000 rpm for $10 \mathrm{~min}$ and filtrate was collected. The metabolites from the filtrates were extracted with an equal volume of chloroform. The metabolites were also extracted from pellet and pooled. The upper aqueous layer was discarded and to remaining chloroform phase, a pinch of sodium sulphate was added to dry off water. It was again centrifuged at $8,000 \mathrm{rpm}$ for $10 \mathrm{~min}$. The clear layer was discarded and chloroform was removed by flushing air. The residue was re-dissolved in $200 \mathrm{ml}$ of acetone and $70 \mu \mathrm{l}$ was spotted on to TLC plate (Silica gel $60 \mathrm{~F} 254,20 \times 20 \mathrm{~cm}, 0.2 \mathrm{~mm}$ thickness, Merck). The plate was chromatogrammed using chloroform: acetone (9:1) as solvent system. Later the plates were observed under UV light at 254 $\mathrm{nm}$. The metabolites were eluted and re-dissolved in acetone:water (1:10). The silica gel clear suspension was further analyzed for toxicity against test pathogen. The percentage inhibition of antibiotic produced by each PGPR strain was calculated as results observed.

\section{Rice cultivation and inoculation}

Seeds of rice were washed thoroughly with distilled water, then surface sterilized with $0.1 \% \mathrm{HgCl}_{2}$ solution for $4 \mathrm{~min}$ and $70 \%$ ethanol for $10 \mathrm{~min}$. The seeds were washed thoroughly with sterile distilled water and kept in a shaker for 5-6 hrs in autoclaved distilled water on a rotary shaker. The seeds were test for possible contamination on tryptone glucose yeast extract agar medium and used for inoculation experiments.

Effect of the isolated bacteria on the biochemical parameters were studied on rice seedlings transferred in culture tubes containing 400 $\mu \mathrm{l}$ Hoagland's nutrient medium, $400 \mu \mathrm{l}$ micronutrients, $1 \%$ agar in $40 \mathrm{ml}$ distilled water and bacterial inoculum of the isolated bacteria in a concentration of $6 \times 10^{8} \mathrm{CFU} \mathrm{ml}{ }^{-1}$. To obtain a mixture of both bacterial cultures, an equal volume of both the cultures were mixed in the medium to give a concentration of $6 \times 10^{8} \mathrm{CFU} \mathrm{ml}^{-1}$. All experiments were carried in 3 replicates. The tubes were incubated at $27^{\circ} \mathrm{C}$ in a 12 hours light-dark cycle in a growth chamber.

\section{Inocula preparation and seedling germination assay}

Strains were grown in yeast manitol broth (YMB) and nutrient broth. Exponentially growing cells in shaken broth culture were inoculated. Rice seeds were surface sterilized by $100 \%$ ethanol in a flask and were treated with $1 \% \mathrm{Na}$ hypochlorite for 2 min followed by six times washing with sterile water. After that, the seeds were soaked in various PGPR broths. Seeds soaked in normal broth were treated as control. Seeds of both inoculated and controls were put in sterilized Petri dishes containing filter paper (Whatman \# 102) and the Petri dishes were kept in an incubator at $30^{\circ} \mathrm{C}$ for $120 \mathrm{hrs}$. After soaking, the air-dried seeds were used for germination and the survival percent.

\section{Effect of isolates as biocontrol agent under greenhouse condition}

Plants were transferred to plastic pots containing sterilized sandperlite (1:1) and kept in a greenhouse. The plants were irrigated with water and with Hoagland nutrient solution once a week. The bacterial isolates, either alone or as a mixture, were assessed for their efficiency in suppressing rice blast under greenhouse conditions. The spore suspension of Magnaprothe grisea with a spore load of $10^{4}$ conidia $\mathrm{ml}^{-1}$ was sprayed on the plants, which caused more than $75 \%$ infection under greenhouse conditions. Observations on the percent disease incidence of rice blast were recorded. In addition, growth parameters like plant height, root length, and dry biomass production were recorded 21 days after planting (maximum tillering). Disease index was calculated as grades 0 to 5 [12] using the formula:

Disease index $=$ Total grade $\times 100 /$ No of sheaths observed $\times$ maximum grade.

\section{Statistical analysis}

Data were analyzed by one way ANOVA (analysis of variance). All treatments were replicated 5 times, with 15 plants per experiment. Differences were considered to be significant at the $\mathrm{P}<0.05$ level. Means were compared by Fisher's protected LSD.

\section{Results and Discussion}

Fungal diseases are primarily controlled by the application of fungicides [13]. However, developing resistance against chemicals is dangerous and not an eco-friendly. Synthetic fungicides are reported to have carcinogenic, teratogenic, oncogenic and genotoxic properties. Further the cost of these fungicides is relatively high. To overcome these problems researchers have put forth PGPR as an alternative which are supposed to have an antibacterial and antifungal properties [14] and also environmental friendly.

In the present study, thirty five bacterial isolates were obtained from the field at botanical garden, S.P university, Gujarat by using semisolid nitrogen-free medium ( $\mathrm{Nfb}$ ), 23 out of 35 were isolated from the root adhere soil samples was rhizosphere and other 12 were isolated from the root of paddy as endorhizosphere. Isolates obtained from rhizosphere and endorhizosphere of rice plants of variety GJ-17 were mostly Gram-negative and non motile. Isolates having different colony character and morphology were selected for further identification. On the basis of phosphate solubilizing ability for 12 continuous days, 8 different isolates were selected for further evaluation (Table 1). Out of these 8 isolates, 3 isolates showing the highest phosphate solubilization activity compared to all others, were selected for further identification. 
Citation: Jha Y, Subramanian RB (2013) Root Associated Bacteria from the Rice antagonizes the Growth of Magnaporthe grisea. J Plant Pathol Microb 4: 164 doi:10.4172/2157-7471.1000164

Page 3 of 6

\begin{tabular}{|c|c|c|c|c|}
\hline Isolates & $\begin{array}{l}\text { Phosphate released } \\
\left(\mu \mathrm{gP} \mathrm{ml}^{-1}\right) \text { on } 3^{\text {rd }} \text { day }\end{array}$ & $\begin{array}{l}\text { Phosphate released } \\
\left(\mu \mathrm{gPml}^{-1}\right) \text { on } 6^{\text {th }} \text { day }\end{array}$ & $\begin{array}{l}\text { Phosphate released } \\
\left(\mu \mathrm{gP} \mathrm{ml}^{-1}\right) \text { on } 9^{\text {th }} \text { day }\end{array}$ & $\begin{array}{l}\text { Phosphate released } \\
\left(\mu \mathrm{gP} \mathrm{ml}^{-1}\right) \text { on } 12^{\text {th }} \text { day }\end{array}$ \\
\hline $1 \mathrm{~A}$ & $26.72^{\mathrm{b}}$ & $97.8^{\mathrm{b}}$ & $152.5^{\mathrm{c}}$ & $230.2^{\mathrm{b}}$ \\
\hline 1B & $31.20^{\mathrm{a}}$ & $183.3^{a}$ & $337.5^{\mathrm{a}}$ & $272.5^{\mathrm{a}}$ \\
\hline $1 \mathrm{C}$ & $16.72^{\mathrm{h}}$ & $77.4^{f}$ & $112.5^{\mathrm{ef}}$ & $137.5^{\mathrm{fg}}$ \\
\hline 1D & $24.48^{\mathrm{bc}}$ & $87.2^{\mathrm{e}}$ & $80.3^{\mathrm{h}}$ & $132.5^{\mathrm{fgh}}$ \\
\hline $2 A$ & $21.72^{\text {def }}$ & $67.8^{\mathrm{h}}$ & $107.1^{\mathrm{fg}}$ & $145.1^{\text {ef }}$ \\
\hline $2 \mathrm{~B}$ & $21.720^{\text {de }}$ & $76.8^{\mathrm{fg}}$ & $126.5^{\text {de }}$ & $157.5^{\text {de }}$ \\
\hline $2 \mathrm{C}$ & $19.48^{g}$ & $94.4^{\mathrm{cd}}$ & $135.2^{\mathrm{d}}$ & $182.5^{\mathrm{c}}$ \\
\hline $2 \mathrm{D}$ & $24.41^{\mathrm{bcd}}$ & $96.23^{b c}$ & $240.5^{b}$ & $178.16^{\mathrm{cd}}$ \\
\hline
\end{tabular}

Values are mean of three replications. Means within columns sharing the same letters are not significantly different ( $p \leq 0.05$; LSD test)

Table 1: Phosphate released in the medium at 3 days interval by the isolates for a period of 12 days $(n=3)$.

\begin{tabular}{|l|l|}
\hline Culture & Positive Biochemical Tests \\
\hline YJ1 & Fermentation, Melibiose, Maltose, Sucrose \\
\hline YJ2 & Esculin, Mannose, Maltose, Trehalose, Indole, Malonate, Sucrose, Colistin, Coumarate, P-Nitrophenyl b-D Galactopyranoside \\
\hline YJ3 & Arabinose, Cellobiose, Melibiose, Mannose, Palatinose, a-Galactosidase \\
\hline
\end{tabular}

Table 2: Biochemical characterization of the isolates.

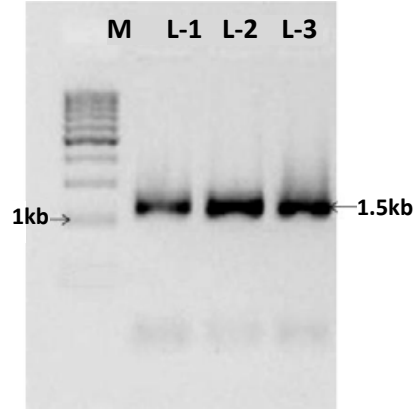

Figure 1: Agarose gel showing the amplified $16 \mathrm{~S}$ rDNA of 3 isolates. $1^{\text {st }}$ lane is $1 \mathrm{kp}$ marker, $2^{\text {nd }}$ lane, $3^{\text {rd }}$ lane and $4^{\text {th }}$ lane are of $16 \mathrm{~S}$ rDNA of $P$. pseudoalcaligenes, Bacillus pumilus and Stenotrophomonas maltophilia having molecular weight of about 1500 bp each respectively from the right hand side.

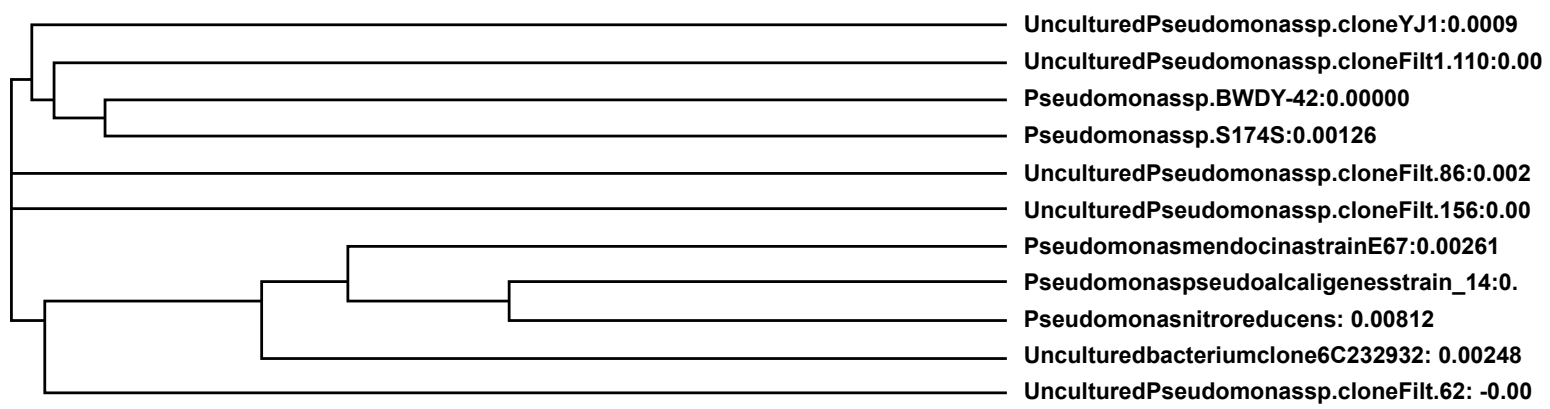

Figure 2: Phylogenetic tree for YJ1, made in online Clustal W software using neighbor joining method and distance matrix.

Phenotypic, biochemical and molecular characterization is a good way to study the ability of strains to metabolize specific compounds, and also good tool for the classification of native isolates. Three isolates from the rhizosphere soil and endorhizosphere respectively were tentatively identified on the basis of biochemical tests and sugar fermentation behavior as described in Bergey's Manual of Determinative Bacteriology. Culture positive for different biochemical tests were indicated in table 2, culture $1 \mathrm{~A}$ named as isolate $\mathrm{YJ} 1$, culture 1B (YJ2) and culture 2D (YJ3).

PCR amplicons of $16 \mathrm{~S}$ rDNA of about 1500 bp was observed as discrete bands on agarose gel (Figure 1). The phylogenetic trees were constructed in MEGA 3.1 software by the comparison of the 16S
rDNA sequence of isolates and related genera from a database using the neighbor-joining (NJ) algorithm and the maximum likelihood (ML) method, which are shown in figures 2, 3 and 4, respectively. The sequences were submitted to NCBI data Bank having accession nos. EU921258, EU921259, and FJ602871. The cultures were identified as Pseudomonas pseudoalcaligenes, Bacillus pumilus and Stenotrophomonas maltophilia respectively. It has been reported that the bacteria from genera Bacillus, pseudomonas, Brevibacillus promoted growth and yield of different non-leguminous plants [15]. In present study, these isolates showed presence of nifH gene which help in nitrogen fixation, although Xie et al. [16] has previously been reported nitrogenase activity in $P$. pseudoalcaligenes which has also been observed in our study (data communicated). Indeed, the root 
Citation: Jha Y, Subramanian RB (2013) Root Associated Bacteria from the Rice antagonizes the Growth of Magnaporthe grisea. J Plant Pathol Microb 4: 164 doi:10.4172/2157-7471.1000164

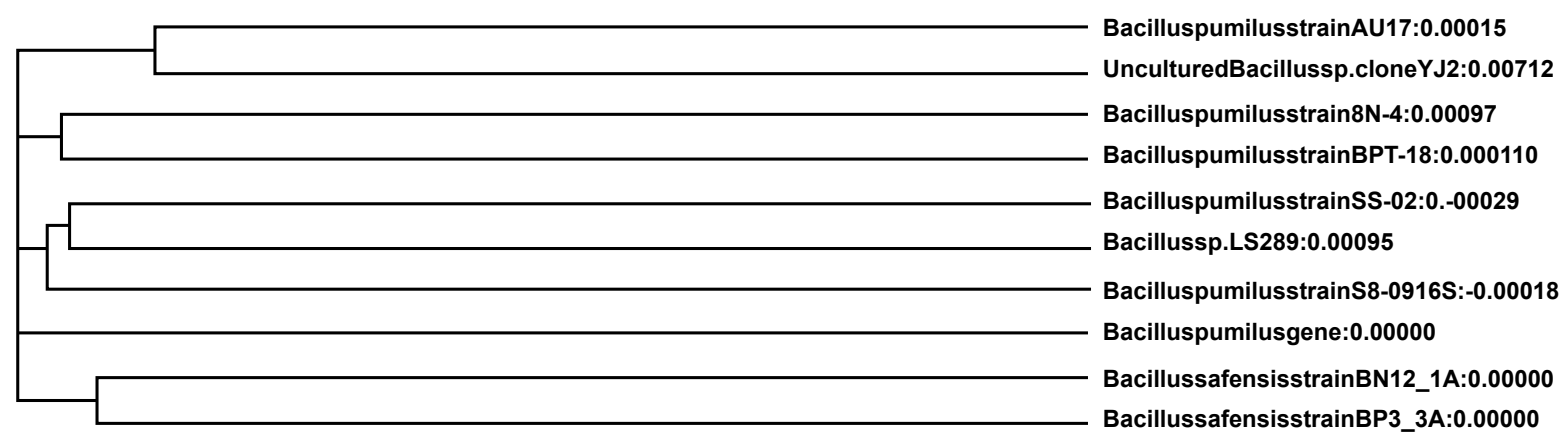

Figure 3: Phylogenetic tree for YJ2, made in online Clustal W software using neighbor joining method and distance matrix.

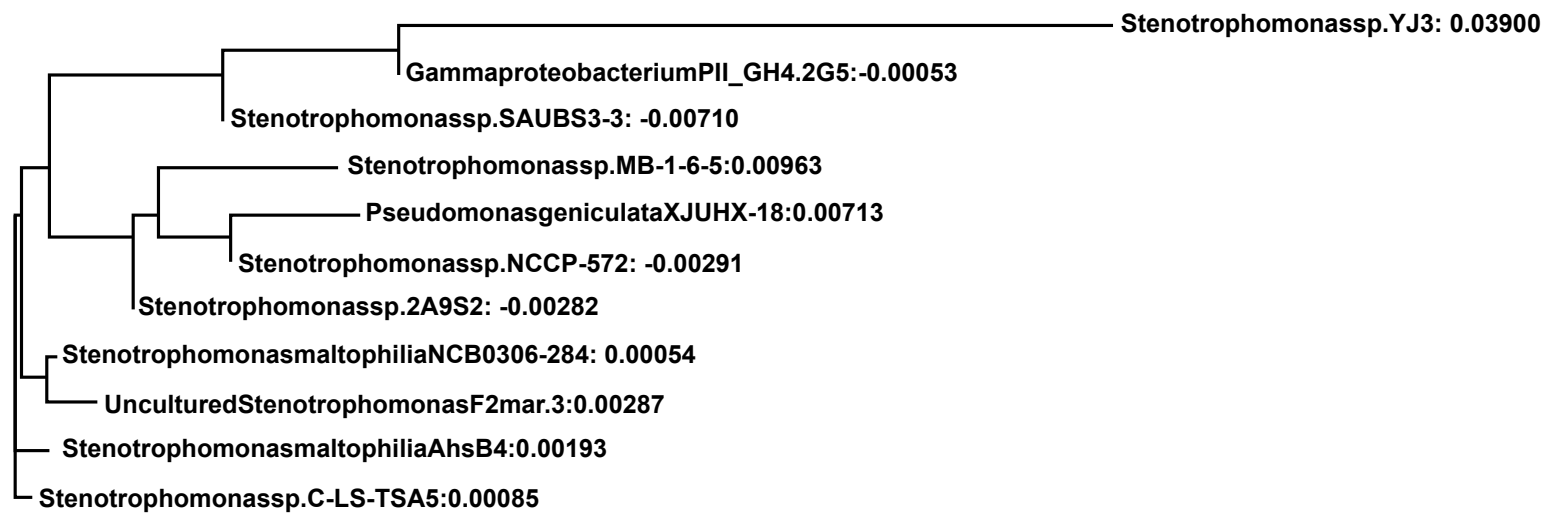

Figure 4: Phylogenetic tree for $\mathrm{YJ} 3$, made in online Clustal W software using neighbor joining method and distance matrix.

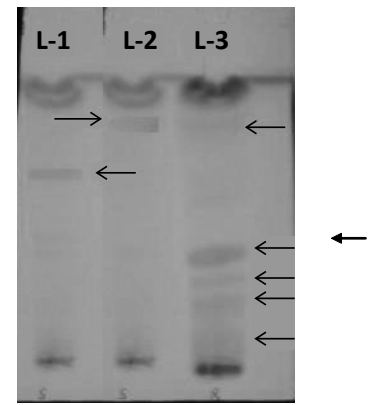

Figure 5: Antibiotic(s) production by PGPR strains on TLC plate. L $-1,2$ and 3 are for Bacillus pumilus, Stenotrophomonas maltophilia and Pseudomonas pseudoalcaligenes, respectively from the right hand side.

associated bacterium showed potential capacity to promote growth of the rice plantlets and very probably in other plant also, a regulatory function play role on the interaction of the plant with other components of rhizosphere [17].

In the present study, these isolates were able to produce antibiotic and help in enhancing plant height, root length, dry weight and also improved disease resistance. The result of the antibiotic assay by the isolates was shown in figure 5 and efficiency of the metabolite has been tested on PDA plate against Magnaporthe grisea. Only few bands were observed in Bacillus pumilus and Stenotrophomonas maltophilia while Pseudomonas pseudoalcaligenes showed five different bands for antibiotic production was observed on TLC plate (Table 3). Zone of inhibition on PDA plate as shown in figure 6 indicated that the metabolite have inhibitory effect on Magnaporthe grisea. The presence of antibiosis was observed against fungus in this study indicated the antagonistic effect of metabolites and chemical characterization of such metabolites are going on. Results obtained from the present study indicates that seeds treated with the isolates showed higher germination and survival percentage compared to non-treated seeds (Table 4), similar findings are reported by Kumar et al. [18]. The present study strongly supports the development of biocontrol strategies using bacterial strains having antagonistic metabolites, to reduce the damage caused by plant pathogens. The findings are supported by Ramamoorthy et al. [19] who reported that PGPR play a vital role in the management of various 
Citation: Jha Y, Subramanian RB (2013) Root Associated Bacteria from the Rice antagonizes the Growth of Magnaporthe grisea. J Plant Pathol Microb 4: 164 doi:10.4172/2157-7471.1000164

Page 5 of 6

\begin{tabular}{|l|c|c|c|}
\hline PGPR Strain & Antibiotic & Rf values & $\begin{array}{c}\text { Zone Of Inhibition, } \\
\text { ZOI (mm) }\end{array}$ \\
\hline Bacillus pumilus & B1 & 0.492 & 8 \\
\hline $\begin{array}{l}\text { Stenotrophomonas } \\
\text { maltophilia }\end{array}$ & S1 & 0.231 & 12 \\
\hline $\begin{array}{l}\text { Pseudomonas } \\
\text { pseudoalcaligenes }\end{array}$ & P1-P5 & $\begin{array}{c}0.20,0.515,0.656 \\
0.781,0.847\end{array}$ & 15 \\
\hline
\end{tabular}

Table 3: Antibiotic(s) production by PGPR and their efficacy against Magnaporthe grisea.

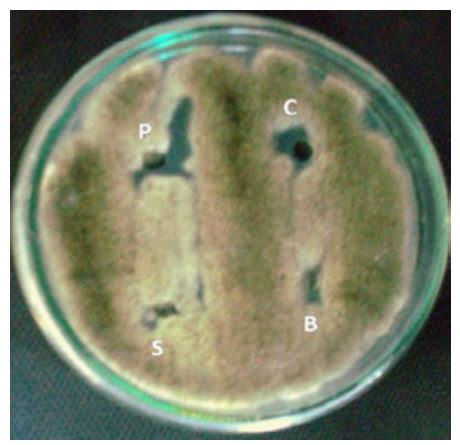

Figure 6: PDA plate showing Zone of Inhibition (ZOI) by the antibiotics produced by PGPR strains against Magnaporthe grisea, $\mathrm{C}=$ contro (phenazines antibiotic), $\mathrm{P}=P$ seudomonas pseudoalcaligenes, $\mathrm{B}=$ Bacillus pumilus and $\mathrm{S}=$ Stenotrophomonas maltophilia.

\begin{tabular}{|l|c|c|}
\hline Treatment & Germination $\%$ & Survival \% \\
\hline Control & $61.1^{\mathrm{h}}$ & $85.7^{\mathrm{h}}$ \\
\hline Control+B. pumulis & $65.4^{\mathrm{g}}$ & $89.1^{\mathrm{fg}}$ \\
\hline Control+P. pseudoalcaligenes & $71.8^{\mathrm{de}}$ & $91.3^{\mathrm{ef}}$ \\
\hline Control+S. maltophilia & $69.2^{\mathrm{ef}}$ & $93.2^{\mathrm{de}}$ \\
\hline Control+B. pumulis+P. pseudoalcaligenes & $78.4^{\mathrm{b}}$ & $112.3^{\mathrm{c}}$ \\
\hline Control+B. pumulis+S. maltophilia & $74.4^{\mathrm{cd}}$ & $98.6^{\mathrm{d}}$ \\
\hline Control+S. maltophilia+P. pseudoalcaligenes & $76.3^{\mathrm{c}}$ & $141.3^{\mathrm{ab}}$ \\
\hline $\begin{array}{l}\text { Control+S. maltophilia+B. pumilus+ } \\
\text { P. pseudoalcaligenes }\end{array}$ & $81.7^{\mathrm{a}}$ & $152.7^{\mathrm{a}}$ \\
\hline
\end{tabular}

Values are mean of three replications. Means within columns sharing the same letters are not significantly different ( $p \leq 0.05$; LSD test).

Table 4: Effect of isolates alone and in combination on the germination and survival percentage.

fungal diseases. In the greenhouse study, the rice plants inoculated with isolates showed significantly higher plant height, root length and dry weight as in table 5. Similarly an increase was also observed in yield of grain and straw (Table 6). Plants inoculated with such isolates also showed higher dry biomass and yield. Wani et al. [20] reported that combination of Pseudomonas strains increased wheat yield and their result does not show much variation to the greenhouse bioassay. In this study, P. pseudoalcaligenes was more effective than B. pumilus and S. maltophilia. Based on these results, P. pseudoalcaligenes, B. pumilus and S. maltophilia in this study are better PGPR. Rhizosphere bacteria and its metabolites that promote plant growth are considered as an alternative to the use of chemicals in agriculture [21]. Important factor to be considered while screening new isolates is their activity in the range of environments and it may be highly specific to certain plant genotypes [22].

So, certainly bacteria represent a potentially valuable tool in highvalue cropping systems like cereals and vegetables, where high use of chemicals leads to contamination. Van Wees et al. [23] suggested that a single bacterium may induce systemic resistance through more than a

\begin{tabular}{|l|c|c|c|c|}
\hline $\begin{array}{l}\text { Bacterial Strain } \\
\text { Co-inoculated }\end{array}$ & $\begin{array}{c}\text { \% Disease } \\
\text { Index }\end{array}$ & $\begin{array}{c}\text { Plant } \\
\text { Height } \\
\text { (cm) }\end{array}$ & $\begin{array}{c}\text { Root } \\
\text { Length } \\
\text { (cm) }\end{array}$ & $\begin{array}{c}\text { Dry } \\
\text { Weight } \\
\text { (g plant }^{-1} \text { ) }\end{array}$ \\
\hline Control & Nil & $68.8^{\mathrm{h}}$ & $11.2^{\mathrm{h}}$ & $2.3^{\mathrm{h}}$ \\
\hline Control+B. pumilus+Pathogen & 43.2 & $70.6^{\mathrm{g}}$ & $13.5^{\mathrm{f}}$ & $2.74^{\mathrm{d}}$ \\
\hline Control+P. pseudoalcaligenes+Pathogen & 38.2 & $77.4^{\mathrm{b}}$ & $17.1^{\mathrm{b}}$ & $3.85^{\mathrm{a}}$ \\
\hline Control+S. maltophilia+Pathogen & 44.6 & $72.3^{\mathrm{ef}}$ & $15.6^{\mathrm{d}}$ & $3.63^{\mathrm{b}}$ \\
\hline $\begin{array}{l}\text { Control+B. pumilus+ } \\
\text { P. pseudoalcaligenes+Pathogen }\end{array}$ & 39.6 & $74.6^{\mathrm{de}}$ & $16.3^{\mathrm{c}}$ & $2.63^{\mathrm{de}}$ \\
\hline $\begin{array}{l}\text { Control+S. maltophilia+ } \\
\text { P. pseudoalcaligenes+Pathogen }\end{array}$ & 36.4 & $76.7^{\mathrm{bc}}$ & $14.1^{\mathrm{e}}$ & $2.41^{\mathrm{f}}$ \\
\hline $\begin{array}{l}\text { Control+S. maltophilia+ } \\
\text { B. pumilus+Pathogen }\end{array}$ & 41.5 & $75.7^{\mathrm{cd}}$ & $12.2^{\mathrm{g}}$ & $2.32^{\mathrm{gf}}$ \\
\hline $\begin{array}{l}\text { Control+S. maltophilia+B. pumilus+ } \\
\text { P. pseudoalcaligenes+Pathogen }\end{array}$ & 31.4 & $82.1^{\mathrm{a}}$ & $18.3^{\mathrm{a}}$ & $2.94^{\mathrm{c}}$ \\
\hline Control+Pathogen & 76.4 & $65.5^{\mathrm{i}}$ & $10.2^{\mathrm{i}}$ & $2.14^{\mathrm{i}}$ \\
\hline
\end{tabular}

Values are mean of three replications. Means within columns sharing the same letters are not significantly different ( $p \leq 0.05$; LSD test)

Table 5: Effect of isolates on disease index and growth parameter under Greenhouse study $(n=3)$.

\begin{tabular}{|l|l|l|}
\hline Treatment & \multicolumn{2}{l|}{ Yield Kg/ha Grain Straw } \\
\hline Control & $704^{\mathrm{i}}$ & $1213^{\mathrm{i}}$ \\
\hline Control+B.pumulis & $841^{\mathrm{h}}$ & $1450^{\mathrm{gh}}$ \\
\hline Contro+P. pseudoalcaligenes & $973^{\mathrm{ab}}$ & $1573^{\mathrm{a}}$ \\
\hline Control+S. maltophilia & $876^{\mathrm{fg}}$ & $1465^{\mathrm{ef}}$ \\
\hline Control+B. pumulis+P. pseudoalcaligenes & $892^{\mathrm{ef}}$ & $1476^{\mathrm{de}}$ \\
\hline Control+ B. pumulis+S.maltophilia & $912^{\mathrm{e}}$ & $1453^{\mathrm{fg}}$ \\
\hline Control+S. maltophilia+P. pseudoalcaligenes & $978^{\mathrm{a}}$ & $1553^{\mathrm{b}}$ \\
\hline Control+S. maltophilia+B. pumilus & $945^{\mathrm{d}}$ & $1487^{\mathrm{d}}$ \\
\hline $\begin{array}{l}\text { Control+S. maltophilia+B. pumilus+ } \\
\text { P. pseudoalcaligenes }\end{array}$ & $961^{\mathrm{bc}}$ & $1526^{\mathrm{c}}$ \\
\hline
\end{tabular}

P. pseudoalcaligenes

Values are mean of three replications. Means within columns sharing the same letters are not significantly different ( $p \leq 0.05$; LSD test)

Table 6: Effect of isolated PGPR on grain and straw yield kg/ha.

single mechanism. The PGPR are ideal organisms for crop protection, because they can be used in various forms to seed or mixed with soil during seedling stage or transplanting. The systemic resistance once induced by PGPR, the natural defense mechanism of the plant is operative for prolonged periods even if population of inducing bacteria decline [24]. We already reported that, in greenhouse study these isolates have the potential to crop under salinity [25]. Further studies are in progress to evaluate the interaction of these PGPR with rice plant under biotic and abiotic stress.

\section{References}

1. Bowen GD, Rovira AD (1999) The rhizosphere and its management to improve plant growth. Advances in Agronomy 66: 1-102.

2. Talbot NJ (2003) On the trail of a cereal killer: Exploring the biology of Magnaporthe grisea. Annu Rev Microbiol 57: 177-202.

3. Mehrotra RS (1998) Plant Pathology. Tata MC Grow Hill Publications. Co. Ltd. New Delhi.

4. Mukherjee B, Sen C (1992) Aspergillus and Penicillium Species: Potential agents for bio control of Macrophomina phaseolina. Indian Phytopathology 45: $39-43$.

5. Amadioha AC (2000) Controlling rice blast in vitro and in vivo with extracts of Azadirachta indica. Crop Prot 19: 287-290.

6. Thakuria D, Talukdar NC, Goswami C, Hazarika S, Boro RC, et al. (2004) Characterization and screening of bacteria from the rhizosphere of rice grown in acidic soils of Assam. Curr Sci 86: 978-985.

7. Cáceres EAR (1982) Improved medium for isolation of Azospirillum species Appl Environ Microbiol 44: 990-991. 
Citation: Jha Y, Subramanian RB (2013) Root Associated Bacteria from the Rice antagonizes the Growth of Magnaporthe grisea. J Plant Pathol Microb 4: 164 doi:10.4172/2157-7471.1000164

8. Cappuccino JC, Sherman N (1992) Microbiology: A Laboratory Manual, Wesley Pub. Co., New York.

9. Xie $\mathrm{CH}$, Yokota A (2004) Transfer of Hyphomicrobium indicum to the genus Photobacterium as Photobacterium indicum comb. nov. Int J Syst Evol Microbiol 54: 2113-2116.

10. Saitou N, Nei M (1987) The neighbor-joining method: A new method for reconstructing phylogenetic trees. Mol Biol Evol 4: 406-425.

11. Kraus J, Loper JE (1995) Characterization of a genomic region required for production of antibiotic Pyoluterin by biogical control agent Pseudomonas fluorescens Pf-5. Appl Environ Microbiol 61: 849-854.

12. Singh PP, Shin YC, Park CS, Chung YR (1999) Biological control of fusarium wilts of cucumber by chitinolytic bacteria. Phytopathology 89: 92-99.

13. Maloy OC (1993) Plant disease control: Principles and practice. John Wiley and Sons Inc., New York.

14. Annapurna Y, Mitra S, lyengar DS, Rao SN, Bhalerao UT (1983) Antimicrobial activity of leaf extracts of Polyalthia longifolia. Journal of Phytopathology 106: 183-185

15. Selvakumar G, Kundu S, Gupta AD, Shouche YS, Gupta HS (2008) Isolation and characterization of nonrhizobial plant growth promoting bacteria from nodules of Kudzu (Pueraria thunbergiana) and their effect on wheat seedling growth. Curr Microbiol 56: 134-139.

16. Xie GH, Cai MY, Tao GC, Steinberger $Y$ (2003) Cultivable heterotrophic $\mathrm{N}_{2}$ fixing bacterial diversity in rice fields in the Yangtze River Plain. Biol Fertil Soils 37: 29-38
17. Hallmann J, Quadt-Hallmann A, Mahaffee WF, Kloepper JW (1997) Bacterial endophytes in agricultural crops. Can J Microbiol 43: 895-914.

18. Kumar A, Sharma S, Mishra S (2009) Effect of alkalinity on growth performance of Jatropha curcas inoculated with PGPR and AM fungi. Journal of Phytology 1: $177-184$.

19. Ramamoorthy V, Raguchander T, Samiyappan R (2002) Induction of defenserelated proteins in tomato roots treated with Pseudomonas fluorescens Pf1 and Fusarium oxysporum f. sp. Iycopersici. Plant and Soil 239: 55- 68.

20. Wani PA, Khan MS, Zaidi A (2007) Synergistic effects of the inoculation with nitrogen-fixing and phosphate-solubilizing rhizobacteria on performance of field-grown chickpea. J Plant Nutr Soil Sci 170: 283-287.

21. Kloepper JW (1993) Plant growth-promoting rhizobacteria as biological contro agents. Soil Microbial Ecology: Applications in Agricultural and Environmental Management. FB Metting Jr. (ed.). Marcel Dekker Inc., New York, USA.

22. Ross DJ, Tate KR, Newton PCD, Wilde RH, Clark H (2000) Carbon and nitrogen pools and mineralization in a grassland gley soil under elevated carbon dioxide at a natural $\mathrm{CO}_{2}$ spring. Glob Chang Biol 6: 779-790.

23. Van Wees SC, Pieterse CM, Trijssenaar A, Van't Westende YA, Hartog F, et al. (1997) Differential induction of systemic resistance in Arabidopsis by biocontro bacteria. Mol Plant Microbe Interact 10: 716- 724.

24. Van Loon LC, Bakker PA, Pieterse CM (1998) Systemic resistance induced by rhizosphere bacteria. Annu Rev Phytopathol 36: 453-483.

25. Jha Y, Subramanian RB, Patel S (2011) Combination of endophytic and rhizospheric Plant Growth Promoting Rhizobacteria in Oryza sativa shows higher accumulation of osmoprotectant against saline stress. Acta Physio Plant 33: 797-802. 